\title{
PERBEDAAN ANTARA PENANGANAN LUKA SNAKE BITE DENGAN INSISI DAN TANPA INSISI TERHADAP KECEPATAN PENURUNAN PEMBENGKAKAN LUKA DI RSUD PACITAN
}

\author{
Akhmad Rifai,Tri Andriani Cholifah \\ Kementerian Kesehatan Politeknik Kesehatan Surakarta Jurusan Keperawatan
}

\begin{abstract}
Abstrack: Snake Bite, Incision And Without Incision, Decreasing Speed Of Wound Swelling. Snake bite has different effects, ranging from a simple wound up to life-threatening and even can lead to death. The principle of first aid for snake bite is to avoid the spread of snake poison and to prevent the infection in the bitten part. In the past, the snake bite was treated by using incision while some sources recently stated that the snake bite is not necessary treated by using incision. This study aims to determine The differences between snake bite wound treatment with incision and without incision toward the decreasing speed of wound swelling at RSUD Pacitan. The study design used non-experimental research method : a comparative with retrospective or historical documentary approach. The samples were taken by using total sampling technique. The sum of the samples was 88 documents. They were taken from medical record documents. The statistic test used Chi square with significant value 0.05. The result of the study showed that there were differences between snake bite wound treatment with incision and without incision toward the decreasing speed of wound swelling at RSUD Pacitan in 2009 - 2011.
\end{abstract}

Keywords : Snake Bite, Incision And Without Incision, Decreasing Speed Of Wound Swelling

\begin{abstract}
Abstrak: Snake Bite, Insisi Dan Tanpa Insisi, Kecepatan Penurunan Pembengkakan. Gigitan ular atau Snake bite mempunyai efek yang beragam, mulai dari luka yang sederhana sampai dengan mengancam nyawa dan menyebabkan kematian. Prinsip pertolongan pertama terhadap gigitan ular adalah menghindarkan penyebaran bisa dan mencegah terjadinya infeksi pada bagian yang digigit. Dulu pernah dikenal penanganan snake bite dengan insisi sementara beberapa sumber saat ini menyebutkan bahwa pada luka snake bite tidak perlu dilakukan insisi. Penelitian ini bertujuan untuk mengetahui perbedaan Antara Penanganan Luka Snake bite dengan insisi dan tanpa Insisi Terhadap Kecepatan Penurunan Pembengkakan Luka di RSUD Pacitan. Desain penelitian ini menggunakan metode penelitian non eksperimen: komparatif dengan pendekatan retrospektif atau documentary-historikal. Pengambilan sampel dengan teknik jenuh sampling dengan jumlah sampel 88 dokumen rekam medis. Uji statistik dengan menggunakan Chi Kuadrat dengan nilai signifikansi 0,05. Hasil penelitian ini adalah ada perbedaan antara penanganan luka snake bite dengan insisi dan tanpa insisi terhadap kecepatan penurunan pembengkakan luka di RSUD Pacitan Tahun 2009-2011
\end{abstract}


Kata kunci : Snake Bite, Insisi Dan Tanpa Insisi, Kecepatan Penurunan Pembengkakan

\section{PENDAHULUAN}

Ular berbisa yang menggigit melakukan envenomasi (gigitan yang menginjeksikan bisa atau racun), bisa ular melewati kelenjar bisa melalui sebuah duktus menuju taring ular, dan akhirnya menuju mangsanya. Bisa ular mengandung berbagai enzim. Enzim yang dikeluarkan ini antara lain hialuronidase, fosfolipase $A$ dan berbagai proteinase yang menyebabkan kerusakan jaringan. Bisa ular menyebar dalam tubuh melalui saluran kapiler dan limfatik superfisial (Sartono, 2002). Efek lokal pada luka gigitan ular berbisa adalah terjadinya pembengkakan yang cepat dan nyeri (Sudoyo, 2010). Korban yang terkena gigitan ular berbisa perlu mendapatkan pertolongan segera. Prinsip pertolongan pertama terhadap gigitan ular adalah menghindarkan penyebaran bisa dan yang kedua adalah mencegah terjadinya infeksi pada bagian yang digigit. Dulu pernah dikenal cara perawatan ala John Wayne yaitu "iris, isap dan muntahkan" (slice, suck and spit) atau tindakan insisi, penghisapan dengan mulut dan dimuntahkan sebagai upaya untuk mengeluarkan bisa dan mencegah penyebaran bisa ke seluruh tubuh (Networkbali, 2010).

Pada kasus snake bite pembengkakan disebabkan karena proses peradangan dan edema yang disebabkan permeabilitas kapiler yang bertambah. Endotel kapiler merupakan suatu membran semi permeabel yang dapat dilalui oleh air dan elektrolit secara bebas, sedangkan protein plasma hanya dapat melaluinya sedikit atau terbatas. Tekanan osmotik darah lebih besar daripada limfe. Daya permeabilitas ini bergantung kepada substansi yang mengikat sel-sel endotel tersebut. Pada keadaan tertentu, misalnya akibat pengaruh toksin yang bekerja terhadap endotel, permeabilitas kapiler dapat bertambah. Akibatnya ialah protein plasma keluar kapiler, sehingga tekanan osmotik koloid darah menurun dan sebaliknya tekanan osmotik cairan interstitium bertambah.

Hal ini mengakibatkan makin banyak cairan yang meninggalkan kapiler dan menimbulkan edema. Pembengkakan luka snake bite disebabkan envenomasi bisa yang mengandung berbagai enzim dan menyebabkan kerusakan endotel, salah satunya enzim cytolytik, zat ini aktif menyebabkan peradangan dan nekrose di jaringan pada tempat gigitan. Efek lokal dari snake bite adalah terjadinya pembengkakan atau edema, nyeri tekan pada luka gigitan, dan ekimosis yang terjadi dalam 30 menit-24 jam. Menurut Sartono (2002) tindakan insisi pada penanganan luka snake bite dapat merusak urat syaraf dan pembuluh darah. Keutuhan jaringan kulit dan membran mukosa merupakan garis pertama untuk pertahanan diri dari mikroorganisme (Corwin, 2003) dengan tindakan insisi menyebabkan kerusakan jaringan kulit dan menyebabkan resiko masuknya mikroorganisme sehingga menimbulkan resiko infeksi yang lebih besar (Potter, 2005).

\section{METODE PENELITIAN}

Jenis penelitian yang digunakan dalam penelitian ini adalah penelitian non eksperimen: komparatif yaitu untuk mencari perbandingan antara dua 
sampel atau dua uji coba pada objek penelitian (Suyanto, 2011). Rancangan ini difokuskan untuk mengkaji perbandingan terhadap pengaruh (efek) pada kelompok subjek tanpa adanya suatu perlakuan dari peneliti (Nursalam, 2008) dengan pendekatan retrospektif atau dokumentaryhistorikal, yaitu mengumpulkan data dari berbagai catatan keperawatan pasien yang telah lalu (Suyanto, 2011). sampel disini adalah dokumen rekam penanganan dengan insisi dan tanpa insisi.

Pengumpulan data pada penelitian ini menggunakan lembar check list dengan teknik dokumentasi. Dokumentasi merupakan kegiatan mencari data dari sumber berupa catatan, buku, dan sebagainya (Saryono, 2011). Lembar check list diisi oleh peneliti berdasarkan data dalam dokumentasi rekam medis. Jenis data yang dikumpulkan merupakan data sekunder. Analisa bivariat pada penelitian ini menggunakan statistik nonparametrik yaitu dengan uji Chi Kuadrat karena data bersifat nominal. Jika n1 + n2 > 40, dapat dipakai test Chi Kuadrat dengan koreksi Yates (Sugiyono, 2007).

\section{HASIL PENELITIAN}

a. Distribusi frekwensi data pasien snake bite menurut umur

Tabel 1

\section{Distribusi frekwensi pasien snake} bite menurut umur medis pasien snake bite yang dilakukan

\begin{tabular}{c} 
tahun \\
$\begin{array}{c}41-50 \\
\text { tahun } \\
>50 \quad \text { tahun }\end{array}$ \\
\hline Jumlah \\
\hline
\end{tabular}

Berdasarkan tabel di atas dapat diketahui bahwa pasien snake bite di RSUD Pacitan tahun 2009 -2011 sebagian besar berumur 21-30 tahun yaitu sebanyak 26 pasien $(29,5 \%)$. Hasil ini sesuai dengan studi yang pernah dilakukan di Amerika Serikat dimana 50\% korban snake bite berada pada rentang usia 18-28 tahun. Pada rentang usia ini adalah usia produktif dimana seseorang banyak melakukan aktifitas dan interaksi dengan lingkungan termasuk resiko untuk terkena snake bite (Andimarlinasyam, 2009).

b. Distribusi frekwensi data pasien snake bite menurut jenis kelamin

Tabel 2

Distribusi frekwensi pasien snake bite menurut jenis kelamin

\begin{tabular}{clcc}
\hline No & $\begin{array}{c}\text { Jenis } \\
\text { Kelamin }\end{array}$ & $\begin{array}{c}\text { Frekuensi } \\
(\mathrm{F})\end{array}$ & Persentase (\%) \\
\hline 1. & Laki-laki & 61 & 69,3 \\
2. & Perempuan & 27 & 30,7 \\
\hline & Jumlah & 88 & 100
\end{tabular}

Berdasarkan tabel di atas dapat diketahui bahwa pasien snake bite di RSUD Pacitan tahun 2009 -2011 sebagian besar berjenis kelamin laki laki yaitu sebanyak 61 pasien ( 69,3\%) dan sebagian kecil berjenis kelamin perempuan yaitu sebanyak 27 pasien ( $30,7 \%$ ). c. Distribusi frekwensi data pasien

\begin{tabular}{cccc}
\hline No & Umur & Frekuensi (F) & Persentase(\%) \\
\hline 1. & $0-10$ & 1 & 1,1 \\
2. & tahun & 9 & 10,2 \\
3. & $11-20$ & 26 & 29,5 \\
4. & tahun & 13 & 14,8 \\
5. & $21-30$ & 14 & 15,9 \\
6. & tahun & 25 & 28,4 \\
\hline
\end{tabular}


Tabel 3

Distribusi frekwensi pasien snake bite menurut pendidikan

\begin{tabular}{clcc}
\hline No & Pendidikan & $\begin{array}{c}\text { Frekuensi } \\
(\mathrm{F})\end{array}$ & $\begin{array}{c}\text { Persentase } \\
(\%)\end{array}$ \\
\hline 1. & SD & \multicolumn{2}{c}{11} \\
& & \multicolumn{2}{c}{12,5} \\
.2 & SMP & 15 & 17,0 \\
3. & SMU & 47 & 53,4 \\
4. & Perguruan & 15 & 17,0 \\
& Tinggi & & \\
\hline & Jumlah & 88 & 100 \\
\hline
\end{tabular}

Berdasarkan tabel di atas dapat diketahui bahwa pasien snake bite di RSUD Pacitan tahun 2009 -2011 sebagian besar berpendidikan SMU yaitu sebanyak 47 pasien $(53,4 \%)$. Menurut Sartono (2002) tingkat pendidikan berpengaruh dalam upaya masyarakat untuk mencari pertolongan dan penanganan dengan antivenom sehingga dapat menurunkan tingkat keparahan akibat racun gigitan ular. Kematian pada kasus gigitan ular di beberapa negara terjadi pada masyarakat miskin pedesaan dengan tingkat pendidikan yang rendah dan akses pelayanan medis yang sulit sehingga berakibat fatal pada korban gigitan ular (Bataviase, 2010)

d. Distribusi frekwensi data pasien snake bite menurut pekerjaan

\section{Tabel 4}

Distribusi frekwensi pasien snake bite menurut pekerjaan

\begin{tabular}{clcc}
\hline \multirow{4}{*}{ No } & \multicolumn{1}{c}{ Pekerjaan } & $\begin{array}{c}\text { Frekuensi } \\
(\mathrm{F})\end{array}$ & $\begin{array}{c}\text { Persentase } \\
(\%)\end{array}$ \\
\hline 1. & Petani & 34 & 38,6 \\
2. & Swasta & 29 & 33,0 \\
3. & PNS & 11 & 12,5 \\
4. & Mahasiswa/pelajar & 13 & 14,8 \\
5. & Pensiunan & 1 & 1,1 \\
\hline \multicolumn{2}{c}{ Jumlah } & 88 & 100
\end{tabular}

Berdasarkan tabel di atas dapat diketahui bahwa pasien snake bite di RSUD Pacitan tahun 2009 -2011 sebagian besar bekerja sebagai petani yaitu sebanyak 34 pasien $(38,6 \%)$. Hasil ini sesuai dengan yang dikemukakan Andimarlinasyam (2009) bahwa gigitan ular lebih umum terjadi di wilayah tropis dan di daerah dimana pekerjaan utamanya adalah petani, karena di daerah-daerah tersebut sejumlah besar orang hidup berdampingan dengan sejumlah besar ular yang ditemui saat bertani di sawah atau ladang, sehingga resiko untuk terkena gigitan ular lebih besar.

e. Distribusi frekwensi data pasien snake bite menurut lokasi gigitan

Tabel 5

Distribusi frekwensi pasien snake bite menurut lokasi gigitan

\begin{tabular}{llcc}
\hline No & Lokasi & $\begin{array}{c}\text { Frekuensi } \\
(\mathrm{F})\end{array}$ & $\begin{array}{c}\text { Persentase } \\
(\%)\end{array}$ \\
\hline 1. & Tangan & 17 & 19,3 \\
& kanan & & 17,0 \\
2. & Tangan & 15 & 36,4 \\
3. & kiri & 32 & 27,3 \\
4. & Kaki & 24 & \\
& kanan & & 100 \\
\hline & Kaki kiri & & \\
\hline
\end{tabular}

Berdasarkan tabel di atas dapat diketahui bahwa seluruh pasien snake bite di RSUD Pacitan tahun 2009 -2011 lokasi gigitan adalah pada ekstremitas dan sebagian besar terkena gigitan pada kaki kanan yaitu sebanyak 32 pasien $(36,4 \%)$. Hal ini sesuai yang dikemukakan Andimarlinasyam (2009) bahwa 95\% gigitan ular terjadi pada area ekstremitas karena ekstremitas adalah bagian tubuh yang melakukan kontak langsung dengan ular yaitu memegang atau menginjak sehingga resiko terkena snake bite lebih besar daripada bagian tubuh yang lain. f. Distribusi frekwensi data pasien snake bite menurut penanganan 
Tabel 6

\section{Distribusi frekwensi pasien snake bite menurut penanganan}

\begin{tabular}{llcc}
\hline No & Penanganan & $\begin{array}{c}\text { Frekuensi } \\
(\mathrm{F})\end{array}$ & $\begin{array}{c}\text { Persentase } \\
(\%)\end{array}$ \\
\hline 1. & Insisi & 17 & 19,3 \\
2. & Tanpa & 71 & 80,7 \\
& insisi & & \\
\hline
\end{tabular}

Jumlah $\quad 88 \quad 100$

Berdasarkan tabel di atas dapat diketahui bahwa pasien snake bite di RSUD Pacitan tahun 2009 -2011 sebagian besar dilakukan penanganan tanpa insisi yaitu sebanyak 71 pasien ( $80,7 \%$ ) dan sebagian kecil dilakukan penanganan dengan insisi yaitu sebanyak 17 pasien ( $19,3 \%$ ).

Penanganan tanpa insisi tersebut sesuai dengan teknik penanganan menurut Sudoyo (2010) yang menyebutkan bahwa tidak boleh dilakukan manipulasi pada area luka termasuk insisi atau eksisi. Sedangkan sebagian kecil pasien snake bite diberikan penangananan dengan insisi, seperti yang dikemukakan Sjamsuhidajat (1997) yaitu melakukan sayatan pada area luka snake bite sebagai upaya untuk mengeluarkan bisa dan mencegah penyebaran bisa ke seluruh tubuh.

g. Distribusi frekwensi data pasien snake bite menurut kecepatan penurunan pembengkakan.

Tabel 7

Distribusi frekwensi pasien snake bite menurut kecepatan penurunan pembengkakan

\begin{tabular}{llcc}
\hline No & Kecepatan & $\begin{array}{c}\text { Frekuensi } \\
(\mathrm{F})\end{array}$ & $\begin{array}{c}\text { Persentase } \\
(\%)\end{array}$ \\
\hline 1. & Cepat & 61 & 69,3 \\
2. & Lambat & 27 & 30,7 \\
\hline & Jumlah & 88 & 100 \\
\hline
\end{tabular}

Berdasarkan tabel di atas dapat diketahui bahwa kecepatan penurunan pembengkakan pasien snake bite di RSUD Pacitan tahun 2009 -2011 sebagian besar dalam kategori cepat yaitu sebanyak 61 pasien ( 69,3\%) dan sebagian kecil dalam kategori lambat yaitu sebanyak 27 pasien ( $30,7 \%$ ). Kecepatan penurunan pembengkakan luka snake bite tersebut dapat dipengaruhi jenis bisa, pemberian anti venom / SABU, pemberian obatobatan, sirkulasi darah, oksigenasi jaringan, umur, nutrisi, dan infeksi (Morison, 2003) dan (Sartono, 2002). Pada gigitan ular yang berbisa kecepatan penurunan pembengkakannya akan lebih lambat dibandingkan dengan ular yang tak berbisa. Kecepatan waktu pemberian antivenom/ SABU sejak awal gigitan juga mempengaruhi tingkat pembengkakan luka snake bite sehingga berpengaruh pada kecepatan penurunan pembengkakannya. Pemberian obat-obatan golongan steroid dapat memberi efek lebih cepat terhadap penurunan oedem/ pembengkakan dibandingkan yang tidak mendapatkan obat-obatan tersebut. Gangguan sirkulasi dan oksigenasi jaringan yang tidak baik akan berpengaruh pada kecepatan penurunan pembengkakan, misalnya yang disebabkan penyakit lain seperti diabetus melitus, kelainan darah, anemi, dan sebagainya dapat menyebabkan sirkulasi dan oksigenasi jaringan pada luka lebih lambat sehingga proses penurunan pembengkakan juga lebih lambat. Menurut Potter (2005) umur berpengaruh terhadap penyembuhan luka termasuk kecepatan penurunan pembengkakan, karena proses penuaan menyebabkan pembentukan jaringan baru menjadi lebih lambat dibandingkan pada usia muda, 
sehingga pada usia di atas 50 tahun kecepatan penurunan pembengkakan lebih lambat dibandingkan pada usia yang lebih muda. Asupan nutrisi dan protein yang cukup akan menunjang pembentukan jaringan baru pada luka menjadi lebih cepat, sehingga penurunan pembengkakan juga lebih cepat, jika nutrisi tidak mencukupi karena kurangnya asupan atau gangguan penyerapan maka pembentukan jaringan baru akan lebih lambat. Sementara faktor infeksi juga berpengaruh pada kecepatan penurunan pembengkakan; penanganan yang tepat, perawatan luka yang baik, serta pemberian antibiotik akan mencegah atau mengatasi infeksi sehingga penurunan pembengkakan luka akan lebih cepat. Nilai Chi Kuadrat diperoleh hasil $\mathrm{X}^{2}$ hitung 7,846. Berdasarkan hasil tersebut dimana $\mathrm{X}^{2}$ hitung $(7,846)$ lebih besar dari $\mathrm{X}^{2}$ tabel $(3,841)$ dengan demikian H0 ditolak dan $\mathrm{H} 1$ diterima yaitu ada perbedaan antara penanganan luka snake bite dengan insisi dan tanpa insisi terhadap kecepatan penurunan pembengkakan luka

\section{Tabel 8}

Tabulasi silang antara penanganan luka snake bite dengan insisi dan tanpa insisi terhadap kecepatan penurunan pembengkakakan luka

\begin{tabular}{cccccccc}
\hline & & \multicolumn{5}{c}{ Kecepatan } \\
\cline { 3 - 7 } No & Penanganan & \multicolumn{2}{c}{ Cepat } & \multicolumn{2}{c}{ Lambat } & Jumlah \\
\cline { 3 - 7 } & & $(\mathrm{F})$ & $(\%)$ & $(\mathrm{F})$ & $(\%)$ & $(\mathrm{F})$ & $(\%)$ \\
\hline 1. & Insisi & 7 & 7,9 & 10 & 11,4 & 17 & $\begin{array}{c}19 \\
3\end{array}$ \\
2. & $\begin{array}{l}\text { Tanpa } \\
\text { Insisi }\end{array}$ & 54 & 61,4 & 17 & 19,3 & 71 & $\begin{array}{c}80, \\
7\end{array}$ \\
\hline & Jumlah & 61 & 69,3 & 27 & 30,7 & 88 & 100 \\
\hline
\end{tabular}

Dari tabel di atas dapat dilihat bahwa penanganan luka snake bite di RSUD Pacitan pada tahun 2009-2011 yang dilakukan insisi yaitu sebanyak
17 pasien (19,3\%), dari 17 pasien tersebut sebagian besar kecepatan penurunan pembengkakan luka dalam kategori lambat yaitu 10 pasien $(11,4 \%)$, sedangkan yang tidak dilakukan insisi yaitu sebanyak 71 pasien $(80,7 \%)$, dari 71 pasien tersebut sebagian besar kecepatan penurunan pembengkakan luka dalam kategori cepat yaitu 54 pasien $(61,4 \%)$.

\section{PEMBAHASAN}

Menurut Sjamsuhidajat (1997) tindakan yang dapat dikerjakan untuk menolong penderita yang digigit ular berbisa adalah dengan mengusahakan membuang bisa sebanyak mungkin dengan menoreh lubang bekas masuknya taring ular sepanjang dan sedalam $1 / 2 \mathrm{~cm}$, kemudian lakukan penghisapan mekanis. Bila tidak tersedia alatnya, darah dapat dihisap dengan mulut asal mukosa mulut utuh tak ada luka. Bisa yang tertelan akan dinetralkan oleh cairan pencernaan. Selain itu dapat juga dilakukan eksisi jaringan berbentuk elips karena ada dua bekas tusukan gigi taring, dengan jarak $21 / 2 \mathrm{~cm}$ dari lubang gigitan, sampai kedalaman fasia otot.

Dari tabel dapat dilihat bahwa penanganan luka snake bite di RSUD Pacitan pada tahun 2009-2011 yang dilakukan insisi sebagian besar kecepatan penurunan pembengkakan luka dalam kategori lambat dan sebagian kecil kecepatan penurunan pembengkakannya dalam kategori cepat. Hal ini dapat terjadi karena penurunan pembengkakan luka snake bite dipengaruhi berbagai sebab antara lain: jenis bisa, pemberian anti venom / SABU, pemberian obat-obatan seperti steroid, sirkulasi darah, oksigenasi jaringan, umur, nutrisi, dan infeksi (Morison, 2003) dan (Sartono, 2002). 
Kecepatan

penurunan pembengkakan luka snake bite yang dilakukan insisi sebagian besar dalam kategori lambat, karena dapat dipengaruhi oleh faktor infeksi, dimana infeksi pada luka snake bite dapat disebabkan karena tindakan insisi atau eksisi yang merusak keutuhan jaringan kulit, urat syaraf, dan pembuluh darah. Keutuhan jaringan kulit dan membran mukosa merupakan garis pertama untuk pertahanan diri dari mikroorganisme, oleh karena itu tindakan insisi dapat menyebabkan resiko masuknya mikroorganisme sehingga menimbulkan resiko infeksi yang lebih besar serta akan mengalami proses penurunan pembengkakan yang lebih lama (Potter, 2005). Selain resiko infeksi tersebut, tindakan insisi pada area gigitan dapat menimbulkan resiko perdarahan dan pembengkakan yang lebih berat terutama pada gigitan yang disebabkan ular jenis Viperidae. Hal ini sesuai dengan yang disampaikan Krisanty et al., 2009 bahwa bisa Viperidae bersifat haemotoksin berakibat haemolitik karena mengandung fosfolipase dan enzim lainnya yang menyebabkan koagulasi dengan mengaktifkan protrombin sehingga mudah terjadi perdarahan dan pembengkakan. Hal tersebut mempengaruhi kecepatan penurunan pembengkakan menjadi lebih lambat.

Faktor usia juga mempengaruhi kecepatan penurunan pembengkakan, dimana sebagian besar pasien snake bite dengan kecepatan penurunan pembengkakan yang lambat adalah pasien lansia yaitu berusia diatas 50 tahun karena pada usia ini pembentukan sel epitel lebih lambat sehingga proses perbaikan jaringan lebih lama, fungsi sel imun yang ada pada kulit juga menurun, sehingga kecepatan penurunan pembengkakan menjadi lebih lambat (Potter, 2005).

2. Penanganan Luka Snake bite Tanpa Insisi Terhadap Kecepatan Penurunan

Penanganan tanpa insisi adalah teknik penanganan luka snake bite dimana tidak dilakukan manipulasi pada daerah gigitan termasuk melakukan insisi atau eksisi pada daerah gigitan (Sudoyo, 2010). Dari tabel 4.8. dapat dilihat bahwa penanganan luka snake bite di RSUD Pacitan pada tahun 2009-2011 yang tidak dilakukan insisi sebagian besar kecepatan penurunan pembengkakan luka dalam kategori cepat dan sebagian kecil dalam kategori lambat . Hal ini dapat terjadi karena penurunan pembengkakan pada luka snake bite yang tidak dilakukan insisi dipengaruhi berbagai faktor.

Sesuai yang dikemukakan Morison (2003) dan Sartono (2002) bahwa kecepatan penurunan pembengkakan luka snake bite dapat dipengaruhi oleh jenis bisa, pemberian SABU, obat-obatan, sirkulasi darah, oksigenasi jaringan, umur, dan infeksi. Resiko infeksi pada luka dapat dikurangi pada penanganan tanpa insisi karena tidak adanya luka terbuka yang merusak jaringan kulit dan mukosa sebagai mekanisme pertahanan tubuh yang utama, selain itu seluruh pasien snake bite juga diberikan penanganan lain seperti pemberian SABU, obatobatan seperti steroid dan profilaksis, pemberian cairan kristaloid, penatalaksanaan pernafasan dan oksigenasi, dan terapi supportif untuk mengatasi efek racun atau bisa ular sehingga mempengaruhi proses penyembuhan luka dan kecepatan penurunan pembengkakan. Selain faktor diatas, karakteristik pasien yang sebagian besar berusia dibawah 50 
tahun juga mempengaruhi proses perbaikan jaringan dan penurunan pembengkakan luka menjadi lebih cepat, karena pada usia tersebut pembentukan epitel dan perbaikan jaringan lebih cepat, dan fungsi imun pada kulit masih baik (Potter,2005), oleh karena itu berdasarkan hasil penelitian didapatkan bahwa sebagian besar pasien snake bite yang tidak dilakukan insisi, kecepatan penurunan pembengkakannya dalam kategori cepat.

Setelah dilakukan analisa bivariat diperoleh $\mathrm{X}^{2}$ hitung 7,846, hasil ini lebih besar dari $\mathrm{X}^{2}$ tabel yaitu 3,841 dengan taraf signifikansi 0,05, hal ini menunjukkan bahwa ada perbedaan antara penanganan luka snake bite dengan insisi dan tanpa insisi terhadap kecepatan penurunan pembengkakan luka. Pasien snake bite yang dilakukan penanganan dengan insisi sebagian besar kecepatan penurunan pembengkakan dalam kategori lambat, sedangkan yang dilakukan penanganan tanpa insisi sebagian besar kecepatan penurunan pembengkakan dalam kategori cepat.

Menurut Potter (2005) keutuhan jaringan kulit dan mukosa merupakan mekanisme pertahanan tubuh yang utama untuk mencegah masuknya mikroorganisme penyebab infeksi, sedangkan tindakan insisi pada luka snake bite akan menimbulkan kerusakan jaringan kulit dan pembuluh darah, meskipun tindakan tersebut bertujuan untuk mencegah penyebaran bisa ke seluruh tubuh namun resiko infeksi luka dan perdarahan lebih besar, dan adanya infeksi akan mempengaruhi kecepatan penyembuhan luka yang salah satu prosesnya adalah penurunan pembengkakan luka. Seperti yang dikemukakan Morison (2003) dan
Sartono (2002) bahwa kecepatan penurunan pembengkakan luka snake bite salah satunya dipengaruhi oleh infeksi.

Hasil penelitian ini menunjukkan bahwa ada perbedaan antara penanganan penanganan luka snake bite dengan insisi dan tanpa insisi terhadap kecepatan penurunan pembengkakan luka, hal ini mendukung apa yang dikemukakan Sentra Informasi Keracunan Nasional Badan POM (2005) dan Sudoyo (2010) bahwa saat ini teknik penanganan dengan metode insisi (pengirisan dengan alat tajam), dan pengisapan tempat gigitan harus dihindari karena tidak terbukti manfaatnya dan tidak efektif untuk mengeluarkan bisa pada pasien snake bite. Teknik penanganan luka snake bite yang tepat akan mempercepat proses kesembuhan luka dan efek lain yang disebabkan racun atau bisa ular.

\section{KESIMPULAN DAN SARAN}

Kecepatan penurunan pembengkakan luka snake bite yang dilakukan insisi di RSUD Pacitan sebagian besar dalam kategori lambat DAN ecepatan penurunan pembengkakan luka snake bite yang tidak dilakukan insisi sebagian besar dalam kategori cepat. Ada perbedaan yang signifikan antara penanganan luka snake bite dengan insisi dan tanpa insisi terhadap kecepatan penurunan pembengkakan luka.

Penanganan diharapkan sesuai dengan keadaan pasien yang mungkin akan menunjukkan manifestasi klinis yang berbeda-beda pada setiap pasien, misalnya penanganan snake bite yang disebabkan jenis ular tidak berbisa hendaknya berbeda dengan penanganan snake bite yang disebabkan ular 
berbisa. Hal ini diupayakan agar dapat memberikan penanganan yang efektif dan efisien pada pasien.

\section{DAFTAR RUJUKAN}

Materi Panduan Pelatihan Basic Cardiac \& Trauma Life Support (BC\&TLS). Jakarta: Emergency Medical Training \& Services EMS 119.

Corwin, Elizabeth J. (2003). Patofisiologi. Jakarta: EGC

Krisanty, Paula.\& Manurung, Santa. (2009). Asuhan Keperawatan Gawat Darurat. Jakarta: CV. Trans Info Media.

Morison. (2003). Managemen Luka. Jakarta: EGC.

Nursalam. (2008). Konsep dan Penerapan Metodologi Penelitian Ilmu Keperawatan. Jakarta: Salemba Medika.

Notoatmodjo, Soekidjo. (2005). Metodologi Penelitian

Kesehatan. Jakarta: Rineka Cipta.
Potter \& Perry.(2005). Buku Ajar Fundamental Keperawatan Edisi 4. Jakarta: EGC.

Priyatno, Duwi.(2011).Buku Saku Analisis Statistik Data SPSS. Yogyakarta: MediaKom.

Sartono. (2002). Racun dan Keracunan. Jakarta : Widya Medica.

Saryono. (2011). Metodologi Penelitian Kesehatan. Yogyakarta: Mitra Cendikia Press.

Sjamsuhidajat. de Jong, Wim. (1997). Buku Ajar Ilmu Bedah. Jakarta: EGC.

Sudoyo, Aru.W. (2010). Buku Ajar Ilmu Penyakit Dalam (Jilid I Edisi V). Jakarta: Interna Publishing.

Sugiyono. (2007). Statistik untuk Penelitian. Jakarta: CV. Alfabeta.

Sugiyono. (2009). Metode Penelitian Kuantitatif dan Kualitatif. Jakarta: CV. Alfabeta.

Suyanto. (2011). Metodologi dan Aplikasi Penelitian Keperawatan. Yogyakarta: Nuha Medika. 